\title{
Images of Marie Curie: How Reputational Entrepreneurs Shape Iconic Identities
}

\author{
Lisa Alaimo \\ LAKEHEAD UNIVERSITY \\ LORI CHAMBERS 2 \\ LAKEHEAD UNIVERSITY
}

ANTONY PUDDEPHATT ${ }^{3}$

LAKEHEAD UNIVERSITY

\begin{abstract}
Marie Curie holds iconic status both within the scientific community and in the wider cultural imagination and collective memory. The first woman to be awarded a Nobel Prize and the only woman to achieve such an honor twice, Curie is widely celebrated as a female pioneer in the sciences and is held up as a model for all, but particularly women, to emulate. She is revered not only as a ground-breaking scientist, but also as a devoted wife and mother who fostered intellectual passion in her own children, one of whom became the second woman to be honored with the Nobel Prize in Science. Echoing Eva Hemmungs Wirten, we argue that the evolution of Curie's status over time offers an opportunity to use meta-biography to understand the layered nature of her reputation. We draw on Gary Alan Fine's theory of reputational entrepreneurship to understand her legacy as a product of collective historical memory. Curie's legacy was not predetermined by the fact that she was a successful scientist; in fact, she was shunned by the public in France in 1911 after it was revealed that she, a widow, had engaged in an affair with a fellow married scientist. A meta-biographical analysis reveals considerable effort was put into reputation building by her Curie herself, her commercial sponsor, and family members. To ignore the earlier iterations of her reputation is to underestimate the challenges she faced as a woman in male-dominated science and in a society that judged her by a sexual double standard. Meta-biography, in conjunction with theories of intellectual reputation building and collective memory, allows us to unearth the complicated layers of Curie's story. It also tells us a great deal about the [sexist] society in which Curie and her supporters had to forge her reputation.
\end{abstract}

${ }^{1}$ Lisa Alaimo, Email: lchambe2@lakeheadu.ca

2Lori Chambers, Email: lchambe2@lakeheadu.ca

${ }_{3}^{3}$ Antony Puddephatt, Email: apuddeph@lakeheadu.ca

Copyright (C) 2018 (Lisa Alaimo Lori Chambers, and Antony Puddephatt). Licensed under the Creative Commons Attribution Non-commercial No Derivatives (by-nc-nd). Available at estsjournal.org. 


\section{Keywords}

Marie Curie; women scientists; science; reputations; biography

\section{Introduction}

Marie Curie holds an iconic status both within the scientific community and in the wider cultural imagination and collective memory (Emling 2012; Gidel 2008; Giroud 1981; Goldsmith 2005; Hemmungs Wirten 2015a; Ivimey 1964; Jardins 2010; Lemire 2001; Macklis 2002; Quinn 1996; Redniss 2010; Reid 1974; Trotereau 2011; Waltar 2004). With her husband, Pierre Curie, and a third collaborator, Henri Becquerel, in 1903 she was the first woman to be awarded the Nobel Prize in Physics, for the discovery of spontaneous radioactivity. After her husband's early death, she replaced him as a professor at the Sorbonne, becoming the first woman to hold such a post, and won her second Nobel Prize, this time alone and in Chemistry, in 1911. She was the first person to achieve this honor twice. Perhaps not surprisingly, Curie is widely celebrated as a female pioneer in the sciences and is held up as a model for all, but particularly women, to emulate. She is revered not only as a ground-breaking scientist, but also as a devoted wife and mother who fostered intellectual passion in her own children, one of whom, Irene Joliot-Curie, became the second woman to be honored with the Nobel Prize in Science. In this context, she is a kind of superwoman of science, achieving the prominence of a man while still fulfilling the gendered expectations of marriage and motherhood. However, she has not always been viewed as a hero(ine).

As Eva Hemmungs Wirten (2015b) has noted, the evolution of Curie's status over time offers an opportunity to use meta-biography to understand the layered nature of her reputation. We also draw on the sociology of intellectuals and reputations (Camic and Gross 2001; Frickel and Gross 2005), and especially Gary Alan Fine's (2001) theory of reputational entrepreneurship, to understand the creation of her identity by active agents working to define her collective historical memory. Curie's legacy was not solely determined by the fact she was a successful scientist; rather, her meta-biography reveals considerable effort was put into reputation building by Curie herself, her commercial sponsor, and family members.

At the time of her first Nobel Prize, Curie was a wife living in the shadow of her husband. With his death, she achieved national prominence as a tragic widow who continued what was initially perceived to be her husband's work. As a woman, however, she was subject to scrutiny in her personal life, and many in France were scandalized by rumors that she had engaged in an affair with a married fellow scientist. Her work in World War One, using her discovery to bring x-rays to thousands of injured soldiers, helped to rehabilitate her reputation. But it was her biography of her husband (Curie 1923), and two promotional tours of the United States, funded by the American Marie Mattingly (Missy) Meloney, which began the process of establishing her status as a scientific icon. This reputation was further cemented in the biography written by her daughter, (Curie-Labouisse 1938), which was also influenced by Missy Meloney. Her granddaughter, Helene Langevin-Joliot, continues to reinforce this legacy by acting as a gatekeeper to personal papers and documents used by contemporary biographers. 
Recent works on Curie, both for adults and for children, exclusively endorse the heroic version of her story (Birch and Birmingham 1996; MacLeod 2004; Venezia 2002; Wishinsky 2003). However, to ignore the earlier iterations of her reputation is to underestimate the challenges she faced as a woman in male-dominated science and in a society that judged her by a sexual double standard. The use of meta-biography, in conjunction with the sociology of intellectuals, as well as theories of reputation building and collective memory, allows us to unearth the complicated layers of Curie's [her] story. It also tells us a great deal about the [sexist] society in which Curie and her supporters had to forge her reputation. In making this argument, we challenge Eva Hemmungs Wirten's $(2015 b, 2)$ assertion that Curie's experience was "so extraordinary that it cannot be abstracted or generalized...[and] the only story Marie Curie can tell us is the one about her."

\section{Methodology and Framework: Meta-biography and Reputational Entrepreneurs}

Biography, as Shortland and Yeo $(1996,1)$ noted, is one of the "most popular yet least studied forms of contemporary writing." Biography has been one of the "principle narrative modes in the history of science" (Greene 1996, 727), and biographies have had enormous popular appeal and commercial success. The reputation of biographies themselves, however, has been ambiguous, as they are often perceived as self-promoting, particularly autobiographies and biographies written by relatives and collaborators, the type of sources that are most common in the Curie story. Hemmungs Wirten $(2015 b, 600)$ has argued traditional biographies like these are often rightly criticized for their reification of the history of science as the story of "so-called great men." As a woman, Curie represents an anomaly in this genre, but studies of her nonetheless reinforce the "discovery myth" and the image of science as an individual, rather than a collective, endeavor (Browne 2010).

Hemmungs Wirten (2015b) argues that "meta-biography," or the use of a set of biographies taken together to consider a biographical subject from a number of narrative angles, can reduce this bias. Rather than learning about her story from the partial perspectives and interests of just one biographer, a meta-biographical analysis allows for the consideration of multiple perspectives on her life. Further, we are able to see how her life and identity take shape over time as a result of these biographies themselves being a part of the reputation-building process. With regard to Marie Curie, Hemmungs Wirten argues a high volume of biographical information exists (the foundational texts of which were written by Curie and her family members), making it possible to conduct a detailed meta-biography of her legacy and reputation. By using these as primary source materials, instead of diaries, lab notes, research papers or personal letters, meta-biography provides a "composite construct of different memory cultures" and illustrates the changeability of historical reputations (Rupke 2008, 140). We are inspired by this methodological approach, and, as such, draw on multiple biographical sources to better understand the construction of Curie's reputation over time. The most important of these sources are Curie's biography of her husband and her daughter's biography of her (Curie 1923; Curie 1938); these are supplemented by evidence and opinions from 23 subsequent biographies of 
Curie, written for both children and adults (Birch and Birmingham 1996; Emling 2012; Gidel 2008; Giroud 1981; Goldsmith 2005; Hemmungs Wirten 2015a, 2015b; Illman 1992; Ivimey 1964; Jardins 2010; Langevin-Joliot 1998; Lemire 2001; MacLeod 2004; Macklis 2002; Miller 2007; Pycior 1993; Quinn 1996; Redniss 2010; Reid 1974; Trotereau 2011; Venezia 2009; Waltar 2004; Wishinsky 2003).

As an interpretive lens for our meta-biographical data, we draw on the sociology of intellectuals perspective, which recognizes so-called individual behavior, success, and reputations are always given life through the social contexts within which individuals find themselves (Camic and Gross 2001; Puddephatt and McLaughlin 2007; Frickel and Gross 2005). Indeed, in developing the Structure of Social Action, Talcott Parsons elevated and ensured the lasting popularity of the work of European thinkers such as Durkheim, Weber, and Pareto, but neglected the American "institutionalists" such as Hamilton and Ayres, whose own theoretical agendas were nevertheless quite in line with his ideas (Camic 1992). Since the ideas of the institutionalists did not seem to be a significant divergence from Parsons' own theoretical agenda, Charles Camic argues, his decision to exclude them must have been a result of their increasingly negative reputation at Harvard, where Parsons was located. Intellectual choices, and the reputational outcomes of the thinkers who are implicated in such choices, cannot be detached from the interpersonal network dynamics in which they are embedded. Indeed, Michelle Lamont (1987) makes a similar case, in the other direction, for how Jacques Derrida became a famous French intellectual. For Lamont, Derrida ascended in stature not only because of the strength of his ideas, but also due to how his reputation was established differently in France-where his popularity was due to his relevance in mainstream culture-and in North America-where his influence relied much more on professional literary institutions and journals. Neil McLaughlin (1998) considers the opposite problem of "how to become a forgotten intellectual," in reference to Erich Fromm, who was once quite popular but quickly went out of fashion due to the disfavor resulting from his attempt to mix ideas from Freudians and Marxists, hence being labeled by both camps as unorthodox. He was also caught in the margins between Sociology and Psychology and slipping between the cracks of professional academia and writing for public audiences, choices that would further harm his reputation in influential circles. These studies of intellectual reputation making are important, since the success of intellectuals cannot be adequately understood without an accurate understanding of how social contexts, networks of relationships, and interpersonal dynamics construct the intellectual biographical subject, and expand or limit his or her opportunities for success.

Gary Alan Fine's (2001) theory of "reputational entrepreneurs" is also useful as a theoretical lens. Fine developed the concept of reputational entrepreneurs to explore both celebrated and demonized figures in collective memory, and prompts us to ask similar questions about how Curie's legacy was formed and sustained. Much like the literature on the sociology of intellectuals, Fine (12) asserts that individuals are not remembered or commemorated by chance. Instead, "reputation must be built by the actions of the artist (or in this case, scientist), his or her significant others, and by those institutions or persons who hope to gain by creating prominence." Such reputational entrepreneurs become "gatekeepers" in "the politics of 
memory," and "with their own interests and patterns of relations, create heroes who are appropriate for distinct groups; they construct plausible claims and appealing warrants in an attempt to persuade others that their interpretation deserves to be accepted" (13). Fine also notes that reputations are always relative to the person in question, the actions of reputational entrepreneurs, the interpretations of audiences, as well as the cultural milieu in which the claimsmaking processes take place. In this context, "the way that we remember historical figures is linked to current concerns" (21).

In these theoretical contexts, Curie's reputational story is particularly interesting from a feminist perspective. Multiple studies have illustrated how women in a range of fields from science to literature and the fine arts face greater barriers in achieving long-standing recognition for their work than do men (Harding 1998; Lang and Lang 2001; Lorber 1980; Spender 1982; Tuchman and Fortin 1984; Tuchman 1980). The "social organization of training, production and distribution influences who can become famous" and systemically disadvantages women (Tuchman and Fortin 1984, 74). Women are more likely to serve as reputational entrepreneurs for men, particularly their husbands, than men are to celebrate the memory and achievements of women, even their wives (Lang and Lang 2001). Not only did and do women have to work harder and achieve more than men for their work to be recognized, but they also have to be particularly persistent, and lucky, for such achievements to be remembered in posterity. Family context and familial connections are also more important in the reputation building of women who are judged if they are not "charming" (Tuchman and Fortin 1984, 77). Moreover, women, even more so than men (Adut 2008; Fine 1997; Gamson 2001), are vulnerable to scandal in the creation of memory and reputation; women's sexual "transgressions" are too often interpreted as a sign of social and "institutional decay" or the decline of the nation and family values (Israel 1997). In this theoretical context, we consider a number of questions. How did the fact that Curie was a woman in a field dominated by men shape the ways in which her story would be presented to, and understood by, the wider public? What elements of her story were most important in establishing her status as a feminist icon and a founding mother of science? What actions threatened her reputation as a woman scientist? How were threats to her reputation countered? Who promoted her public visibility, and when and why were such efforts successful?

We argue that five core reputational entrepreneurs, over three broad periods of time, created the image of Marie Curie as female pioneer in science that is now so engrained in the popular imagination. In the early years of her career, Marie Curie's husband, Pierre Curie, made it possible for Curie to engage in scientific inquiry and ensured her contributions to their work would be recognized in the wider scientific community. After Pierre's untimely death, Curie herself continued her scientific discoveries and worked actively, both in writing her biography of Pierre Curie and through promotional tours in the United States sponsored by Marie Meloney, to establish her reputation and to obtain funds for further research. In the years immediately after Marie Curie's death, her daughter, Eve Curie-Labouisse, published what remains the most influential biography of Curie and established the Curie family legacy. This iconic family status has been carefully guarded and reinforced into the present by Helene Langevin-Joliot, Curie's granddaughter. 


\section{The Early Years: Pierre Curie as Reputational Entrepreneur}

Through his insistence that his wife be recognized for her intellectual contributions to their joint work, Pierre Curie was Marie Curie's first "reputational entrepreneur." The two met in the scientific community in Paris. At the time, Pierre Curie, aged 35, was established in the field of physics, and Marie Sklodovska, aged 26, was a graduate student. Pierre Curie was already well known for his pioneering work in crystallography, magnetism and piezoelectricity. The couple married on July 26, 1895, and commenced a successful eight-year partnership. In 1897, they began their famous collaborative research on radioactive elements (Curie 1938). Together, the Curies proved the emission of rays was an atomic property they would call radioactivity. Marie Curie discovered two elements that were active in emitting radioactive rays: polonium and radium. This discovery led to her, along with Pierre Curie and Henri Becquerel, being awarded the Nobel Prize in 1903. Initially, Marie Curie was not to have been included in this honor. Instead, Marie Curie, "absorbed in the persona of her husband," was regarded simply as Pierre Curie's collaborator and assistant (Pycior 1993, 314). Pierre Curie was going to be awarded the Nobel Prize without mention of her. She was depicted as "the little woman behind the great man" (Kohlstedt 2004, 3). However, Pierre Curie pleaded her contribution be recognized. Although she sat silent while her husband and colleague publicly accepted their joint honor, she nonetheless gained international legitimacy as a scientist. Yet while Marie Curie continued her understated and unpaid work, Pierre Curie was promoted to a professorship at the Sorbonne and became a member of the French Academy of Sciences (Kohlstedt 1999, 5). This should not be surprising. At the time, under French civil law, Marie Curie was not a legal person, and could not claim ownership of her intellectual property. As Hemmungs Wirten (2015a, 18) astutely observes, "by reserving the category of person for men only, the sexing mechanisms of the law fashioned the interpretative possibilities surrounding the authority, autonomy, and authorship that came with their collaboration" (Hamilton 2009; Naffine 1998).

Still, relative to other women in the sciences, Marie's supportive husband provided distinct advantages. Other women worked in labs and helped in scientific discoveries in this era, but they did not have husbands (or other male advocates) who were powerful in the scientific community and/or who publicly recognized and promoted the value of the work performed by them (Bergland 2008). In this way, Pierre was Marie's first, and perhaps most important, reputational entrepreneur. Without this support, she might have continued to work in the background, unrecognized by her contemporaries and forgotten in posterity. Helena Pycior (1993) argues Curie would have been unlikely to have a noteworthy career at all without having been married to a prominent male scientist.

Marie and Pierre continued to collaborate until Pierre's sudden and tragic death in 1906, but while he was alive, she was "an irreplaceable sidekick, a collaboration-curiosity" (Hemmungs Wirten 2015b, 602); his death may, ironically, have been the most important moment in the creation of her independent legacy and reputation. She replaced her husband as professor at the Sorbonne, becoming the first woman to hold such a post, and took over his laboratory. In 1911, Marie Curie was awarded her second Nobel Prize, for the discovery of radium. Her reputation as Pierre's long-term collaborator, and her respectability as his obviously adored wife, and then 
widow, allowed her to continue her scientific pursuits. As a widow, however, she was also subject to very gender-specific expectations regarding her behavior outside of the laboratory.

\section{Marie Curie and Missy Meloney: Scandal and Reputational Rehabilitation}

In 1911 Curie was publicly accused of engaging in an illicit affair with a married colleague and thereby became the object of scandal and ridicule, despite her considerable scientific accomplishments. Her reputation was damaged precisely because she was a woman; the man with whom she was accused of having an affair, fellow scientist, Paul Langevin, was not subjected to similar public ridicule or shaming. Media depicted Curie as a "home wrecker," a "dissolute woman," and a "temptress" (Goldsmith 2005, 173). Ultimately, five duels were fought over Curie's honor in 1911, one by Paul Langevin himself (Hemmungs Wirten 2015a, 47). Curie's colleagues requested her dismissal at the Sorbonne. In response, Curie shied away from the press. There was no way in which words could have defended an adulterous woman from infamy in early twentieth century France. Instead, she used actions to mend her reputation with the public. First, she quietly continued with her research program at the Sorbonne, also mentoring her own daughter. Second, with the outbreak of the First World War, she selflessly devoted herself to the Allied cause. From 1914 to 1918 she used her discoveries to assist the Red Cross (Reid 1974, 231). She equipped numerous radiological cars and set up over 200 radiological posts for treating the bullet wounds of injured soldiers. X-ray technology was used to locate bullets, aiding in their removal. Over 1,100,000 people passed through these radiological posts in 1917-1918. This hard work simply could not be ignored by the French public. Nursing the wounded was a very feminine task; despite Curie's non-traditional use of her own new technology, "caring for the wounded in battle had always been the kind of heroism women could aspire to without rocking the boat too much" (Hemmungs Wirten 2015a, 110). Her feminine war efforts were celebrated in print in France in La radiologie et la guerre, in 1921, aiding in the rehabilitation of her reputation.

Moreover, her research and her volunteerism captured the attention of American socialite and journalist, Marie (Missy) Meloney, who organized Curie's tour of the United States in 1921. There she spoke to huge audiences and Meloney implored her to tell Americans about her life, not simply about the life of her husband. In the new, and specifically American, postwar context of flappers and sexual liberation, women's rights and suffrage, Curie refashioned herself for public consumption. Roger Finney, a prominent sociologist in the 1930s, asserted that after the Great War "almost every aspect of the moral code [was] subject to skepticism, discussion and nonconformity" (Finney 1930, 207); in this context, audiences were receptive to a woman scientist. Roger Macklis $(2002,1648)$ asserts that Curie "was by nature shy, reserved, and understated, but with Meloney helping to manage her image, her fame, as both a scientist and as an exemplar of a liberated professional woman of the roaring twenties, grew to superstar

4 Kali Israel has described a similar process in the rehabilitation of the reputation of Virginia Crawford, the adulteress in a high profile divorce in Britain, who thereafter publicly adopted a very religious persona and engaged in good works (Israel 1997, 12). 
proportions." In promoting the tour, Meloney characterized Curie as hardworking, deserving, and in dire need of funding for her "very important research," the potential of which had clearly been illustrated by Curie's work during the Great War. She also convinced Curie to face the press and, in her first public interview, Curie spoke of herself "as a poor scientist, living humbly, dedicated to her work and her children," elements of her biography which would be emphasized by later writers (Singer 2002). Meloney reportedly paid off American media sources to prevent them from publicizing anything related to Curie's affair with Langevin. Instead, Curie's womanly reputation was rehabilitated by emphasis on her love for her husband and her devotion to her children. By selective omission and by celebration of Curie's maternal role, Meloney was engaging in reputational entrepreneurship as she attempted to preserve positive aspects of Curie's identity (Campion and Fine 1998). Meloney also drew connections between Curie's discoveries and cancer research, suggesting that future research might provide a cure.

The tour was an enormous financial success, but it also led to the opportunity for Curie to engage in her most important activity for the rehabilitation of her reputation: her own biography of her husband, published in 1923. As Eva Hemmungs Wirten (2015b, 602) notes, "not many people today remember that Curie was her husband's biographer and fewer still can probably claim to have read Pierre Curie." But writing the biography gave Curie a unique opportunity not only to chronicle the life of her husband and collaborator, but also to fashion her own reputation for posterity. Hemmungs Wirten $(2015 \mathrm{~b}, 605)$ argues the use of "I" and "we" throughout the text suggests Curie "very consciously used the biography of her husband to articulate her own role with respect to the science of radioactivity and to the 'ownership' of radium."

The book, while now largely forgotten, was very popular at the time of its writing and consolidated the public perception that Curie was herself a dedicated and successful scientist. The book also emphasized the familial nature of the Curies' approach to science and their mutual dedication to their children and family life; the fact that the biography ended with the death of Pierre allowed Curie to evade the entire question of her association with Langevin and to emphasize the mutual devotion of the Curies as scientists, as a couple, and as a family. With the publication of this book, the celebrity status Curie had built in America in 1921 became international, her reputation in France was restored, and a second tour of America followed in 1929. The tours allowed Curie to raise money to build a new laboratory, the Institute Du Radium: Pavilion Curie. Half of the building was assigned to Marie Curie for her to use to continue to study radioactivity, while the other half was dedicated to cancer treatment research. The creation of the Institute guaranteed Curie scientific independence and the ability to continue her research (and, by that time, the research being conducted by her scientist daughter, Irene Joliot-Curie). Although Curie herself always spoke of the Institute as a tribute to her late husband, by the time of its construction she was much more famous than he had ever been, and the Institute has provided an on-going testament to Marie Curie's scientific work and a concrete guarantee her own name will not be forgotten. 


\section{Eve Curie and Helene Langevin-Joliot: Formal Biography and the Familial Curation of Memory}

The successful refashioning of Curie's reputation by Curie and Meloney became fully evident at the time of her death in 1934. Her obituary, written by fellow scientist and friend, Lord Rutherford, described her as "the foremost woman investigator of our age" (Rutherford 1934, 673). This image was cemented in the exceptionally popular biography of Curie, written by her daughter, and later both published as a serial in the Saturday Evening Post and adapted by MGM in a Hollywood movie (Hemmungs Wirten 2015a, 145). At the time of her mother's death, Eve Curie was an aspiring writer and journalist. It was Marie (Missy) Meloney who convinced Eve Curie to write a biography of her mother: Madame Curie. The biography was published on November 30, 1936, just short of two years after Marie Curie's death (with the English version published in 1938). While Marie Curie's biography of her husband is now largely forgotten, Eve Curie's biography of her mother remains a foundational text for those interested in the history of the Curie family. The publication date of the work is telling. Eve Curie was able to offer the first posthumous interpretation of the life of her famous mother. This biography set the tone for future accounts and commemoration. Nearly 400 pages in length, the biography described Curie as selfless and emphasized her scientific passion and the importance of her discoveries for human well being. Curie was described in heroic terms throughout the book: "one would like to tell her story like a legend" (Curie 1938: 1).

Like Marie Meloney, Eve Curie (1938) selectively omitted details of her mother's life, and focused instead on her mother's scientific achievements and her devotion to her family. For example, she wrote the following: "A scientist, devoted to her work, whose life was dignified, reserved, and in recent years especially pitiable, was accused of dishonoring the name she bore with brilliance" (Curie 1938, 272). Indeed, this was a passionate defense of Marie Curie and a clear example of Eve's efforts to shape her reputation. The descriptions of family life and of science as a familial passion and pursuit, begun by Marie Curie herself in her biography of her husband, were deepened in this work. In part, this emphasis on family countered accusations Curie had been a home wrecker, and in part it furthered the wider Curie family legend. But the details regarding family life were extensive; such information was and is often absent in the biographies of so-called great men of science for whom home and family life are considered not only irrelevant, but even a potential distraction from the work of science. The image of Curie endorsed in this biography as devoted wife, mother, and scientist has achieved significant staying power in the collective memory and most recent publications continue to rely heavily on Madame Curie as a primary source (Emling 2012; Goldsmith 2005; Waltar, 2004).

Eve Curie-Labouisse's work as a guardian of the reputation of the Curie family has been taken over by Helene Langevin-Joliot, Marie Curie's granddaughter. As Eve Curie-Labouisse's niece, daughter of Irene Joliot-Curie (Curie's other child), and wife of Michel Langevin (grandson of Paul Langevin), Helene Langevin-Joliot remains an active reputational entrepreneur advancing the reputations of both her grandmother and her own mother. Langevin-Joliot is herself a nuclear physicist at the University of Paris and in her 90s remains in charge of a number of Marie Curie programs and campaigns associated with the Institute. She distributes awards in 
honor of her late grandmother and has entertained several different interviewers and audiences (Emling 2012). Additionally, she has written biographical accounts (Langevin-Joliot 1998) and introductions / prologues to historical biographies by both Alan Waltar (2004) and Shelley Emling (2012). In aiding biographers, Joliot-Curie answers questions in text and in person. Upon request, she allows access to Marie Curie's memoirs and research notes. Langevin-Joliot confirms and legitimatizes the legacy past reputational entrepreneurs created, emphasizing her grandmother's passionate devotion to both scientific inquiry and her family.

\section{Conclusion}

Building on the sociology of intellectuals and reputations, and utilizing the methodology of metabiography, we argue that Marie Curie's reputation was constructed and reconstructed over time, through the work of a number of important reputational entrepreneurs (Fine 2001). The work of these reputational entrepreneurs has ensured that today Curie is remembered as a popular icon and scientific heroine (Mills 2007; Turnbull 2007). Books for children, in particular, portray her as an example to be emulated and celebrate that her "accomplishments encouraged girls and women around the world to become scientists" (MacLeod 2004, 29). Curie is described as heroic for her extreme commitment and perseverance in her research. In making this point, authors emphasize the connection between her selfless work and her premature death due to pernicious anemia, linked to radiation exposure (Illman 1992). In this way, Marie Curie thus became an inspirational female and a martyr for science. Importantly, and perhaps ironically, given the reputational challenges she faced in 1911, she is also remembered as a devoted wife and mother, a superwoman of science who managed to have and do it all: not only was she a path-breaking scientist; she also maintained a loving marriage and exemplified devotion to two daughters who themselves were ultimately very successful. For Curie to be adequately recognized for her contributions to science, therefore, she had to conform to a script specific to women; her reputation, unlike that of her male peers, was shaped not only by her scientific achievements, but also by her so-called womanly virtues.

Her story illustrates both the specific challenges faced by a woman scientist in a world in which she was subjected to a sexual double standard and the collective, variable, and political nature of reputations more generally. While we agree with Hemmungs Wirten's (2015a, 162-164) assertions that Curie has become a "brand" and that she "consciously and creatively managed her persona so that it got her what she wanted," we add that she could not have been successful in doing so on her own. Reputation building requires collective effort, and, as the Curie story illustrates, reputations can be made and re-made over time and generations. How and why certain aspects of an individual's past come to dominate one's reputation (while other issues are muted over time) tell us much not only about the individual whose biography we examine, but also about the cultures in which reputations are built. We suggest that meta-biography as a methodology, in combination with the theory of reputational entrepreneurship and the sociology of intellectuals and scandal, offers significant potential for the exploration of the changing nature of individual reputations, and the cultural contexts in which biographies are written and 
promoted. This combination of methodology and theoretical approach is perhaps particularly useful in a feminist context. To what degree can we fully know our subject when unpopular aspects of the story must be muted? What do the stories we tell (and don't tell) about our hero(ine)s suggest about gendered expectations of women, not only in the past, but into the present, in the laboratory and in the home?

Gary Alan Fine (2001) has taught us about the importance of reputations, particularly those which become difficult because of competing narratives from interested groups. Indeed, the stakes for Marie Curie's reputation could not be higher when one realizes her iconic importance to the progress of women in science and for feminism in general. How Curie is defined has farreaching implications, not only for her own reputation and her familial legacy, but also for our collective understanding of the gendered aspects of science. Yet Curie's reputation was not built over night. Using meta-biography, we noted three major moments or waves in which Curie's reputation was most significantly established. We believe similar methods could be fruitfully deployed to investigate the construction of the reputations of other iconic scientists (and leaders in other fields), particularly those having to prove their mettle from marginalized social positions-gendered, to be sure, but also racial and colonial relations (Harding 1998). Metabiography and reputational entrepreneurship may be particularly helpful in unearthing contextually-based understandings of iconic reputations, since combining "partial perspectives" (Haraway 1988) of biographers, who themselves occupy varied, but highly interested, positions, may be the key to understanding reputational constructs within wider structures of power relations.

\section{Author Biography}

Lisa Alaimo completed her M.A. in Sociology and Women's Studies at Lakehead University and this paper is based on the research from her project.

\section{Author Biography}

Dr. Lori Chambers is Professor in Women's Studies at Lakehead University where she teaches feminist theory and a variety of courses related to women and the law.

\section{Author Biography}

Antony Puddephatt is Associate Professor in the Sociology Department at Lakehead University, Canada. His research interests include the social pragmatism of George Herbert Mead, science and technology studies, qualitative methods, environmental sociology, and the sociology of knowledge. He is co-editor of Ethnographies Revisited: Constructing Theory in the Field (Routledge, 2009), and Microsociological Perspectives for Environmental Sociology (Routledge, 2017). 


\section{References}

Adut, Ari. 2008. On Scandal: Moral Disturbances in Society, Politics and Art (Structural Analysis in the Social Science). Cambridge: Cambridge University Press.

Bergland, R. 2008. Maria Mitchell and the Sexing of Science: An Astronomer among the American Romantics. Boston: Beacon Press.

Birch, Beverly and Christian Birmingham. 1996. Marie Curie's Search For Radium. New York: Barron's Educational Series.

Bromberg, Minna and Gary Alan Fine. 2002. "Resurrecting the Red: Pete Seeger and the Purification of Difficult Reputations." Social Forces 80 (4): 1135-1155.

Browne, J. 2010. "Making Darwin: Biography and the changing representations of Charles Darwin." Journal of Interdisciplinary History, 40(3): 347-373.

Camic, Charles. 1992. "Reputation and Predecessor Selection: Parsons and the Institutionalists." American Sociological Review, 57(4): 421-445.

Camic, Charles and Neil Gross. 2001. "The New Sociology of Ideas," pp 236-249 in Judith R. Blau (ed.) Blackwell Companion to Sociology. Maldan, MA: Blackwell Publishing.

Campion, Amy and Gary Alan Fine. 1998. "Main Street on Main Street: Community Identity and the Reputation of Sinclair Lewis." Sociology Quarterly 39 (1): 79-99.

Curie, Eve. 1938. Madame Curie. Paris: Editions Gallimard.

Curie, Marie. 1923. Pierre Curie and "Autobiographical Notes." New York: Macmillan.

Emling, Shelly. 2012. Marie Curie and her Daughters: The Private Lives of Sciences First Family. New York: Palgrave Macmillan.

Fine, Gary Alan. 2001. Difficult Reputations: Collective Memories of the Evil, Inept, and Controversial. Chicago, IL: University of Chicago Press.

Fine, Gary Alan. 1997. "Scandal, social conditions and the creation of public attention: Fatty Arbuckle and the 'Problem of Hollywood.'" Social Problems, 44: 297-321.

Finney, Ross. 1930. “A Sociologist's view of character education." Religious Education 25: 207.

Frickel, Scott and Neil Gross. 2005. "A General Theory of Scientific/Intellectual

Movements." American Sociological Review, 70(2): 204-232.

Gabel, Ines. 2013. "Historical Memory and Collective Memory: West Bank Settlers

Reconstruct the Past." Media, Culture \& Society 35(2): 250-259.

Gamson, Joshua. 2001. “Normal Sins: Sex Scandal Narratives as Institutional Morality Tales." Social Problems 48 : 185-205.

Gidel, H. 2008. Marie Curie. Paris: Groupe Flammarion.

Giroud, F. 1981. Une Femme Honorable. Paris: Fayard.

Goldsmith, Barbara. 2005. Obsessive Genius: The Inner World of Marie Curie. New York: W.W. Norton.

Greene, M.T. 1996. "Writing Scientific Biography," in M. Shortland and R. Yeo (eds.), Telling

Lives in Science: Essays on Scientific Biography. Cambridge: Cambridge University Press.

Hamilton, S. 2009. Impersonations: Troubling the Person in Law and Culture. Toronto: University of Toronto Press.

Harding, Sandra. 1998. Is Science Multicultural? Postcolonialisms, Feminisms, and Epistemologies. 
Indiana, IN: Indiana University Press.

Haraway, Donna. 1988. "Situated Knowledges: The Science Question in Feminism and the Privilege of Partial Perspectives." Feminist Studies, 14(3): 575-599.

Hemmungs Wirten, Eva. 2015a. Making Marie Curie: Intellectual Property and Celebrity Culture in an Age of Information. Chicago: University of Chicago Press.

. 2015b. "The Pasteurization of Marie Curie: A (meta)biographical experiment." Social Studies of Science 45(4): 597-610.

Illman, John. 1992. “Curie's Legacy Without Equal.” Calgary Herald, Nov 28.

Israel, Kali. 1997. "French Vices and British Liberties: Gender, class and narrative competition in a late Victorian sex scandal." Social History 22: 1-26.

Ivimey, A. 1964. Marie Curie. New York: Praeger Publishers.

Jardins, J. Des. 2010. The Madame Curie Complex: The Hidden History of Women in

Science. New York: The Feminist Press.

Kean, Sam 2010. “Marie Curie, Femme Fatale." Canadian Newsstand Major Dailies August 18, A13.

Kohlstedt, Sally, Gregory. 1999. History of Women in the Sciences: Readings from Isis. Chicago and London: University of Chicago Press.

Lamont, Michele. 1987. "How to Become a Dominant French Philosopher: The Case of Jacques Derrida." American Journal of Sociology, 93(3): 584-622.

Lang, Gladys and Lang, Kurt. 2001. Etched in Memory: The building and survival of artistic reputation. University of Illinois Press.

Langevin-Joliot, Helene. 1998. "Radium, Marie Curie and Modern Science." Radiation Research 150(5): S3-S8.

Lemire, L. 2001. Marie Curie. Paris: Perrin.

Lorber, Judith. 1984. Women Physicians: Carers, Status and Power. New York: Tavistock.

MacLeod, Elizabeth. 2004. Marie Curie: A Brilliant Life. Toronto: Kids Can Press.

Macklis, Roger M. 2002. “Scientist, Technologist, Proto-Feminist, Superstar." Science 295 (5560): 1647-1648.

McLaughlin, Neil. 1998. "How to Become a Forgotten Intellectual: Intellectual Movements and the Rise and Fall of Erich Fromm." Sociological Forum, 13(2): 215-246.

Miller, Connie. 2007. Marie Curie and Radioactivity. Minnesota: Capstone Press.

Mills, Don. 2011. "Greatest Polish Woman of All Time to be Honoured with Special Events." Canadian Newsstand Major Dailies March 08, p. 44.

Naffine, N. 1998. "The legal structure of self-ownership: Or the self-possessed man and the woman possessed." Journal of Law and Society 25 (2): 193-212.

Nye, Mary Jo. 2006. "Scientific Biography: History of Science by Another Means?" The University of Chicago Press 97(2): 322-329.

Puddephatt, Antony and Neil McLaughlin. 2007. "The Sociology of Knowledge," pp. 239-248 in Clifton D. Bryant and Dennis L. Peck (eds.) 21" Century Sociology: A Reference Handbook, Volume 2. Thousand Oaks, California: Sage Publications.

Pycior, Helena M. 1993. “Reaping the Benefits of Collaboration While Avoiding its Pitfalls: Marie 
Curie's Rise to Scientific Prominence." Social Studies of Science 23(2): 301-323.

Quinn, S. 1996. Marie Curie: A Life. Boston: Da Capo.

Redniss, L. 2010. Radioactive: Marie and Pierre Curie, a Tale of Love and Fallout. New York: It Books.

Reid, R. 1974. Marie Curie. London: Collins.

Rupke, N.A. 2008. "Letter to the editor." Isis 99(1): 140.

Russell, Nicolas. 2006. "Collective Memory Before and After Halbwachs." The French Review, 79(4): 792-804.

Rutherford, Ernest. 1935. "Obituary: Marie Curie." Slavonic \& East European Review, 13(39): 673676.

Schabas, Margaret. 1999. “The Daughters of Marie Curie Rap at Science's door HAS FEMINISM CHANGED SCIENCE?" The Globe and Mail, May 29, D10.

Schawarcz, Joe. 2011. "The Woman Who Opened Nuclear Age; The Right Chemistry.” The Gazette May 07, B5.

Shortland, M. and R. Yeo (eds). 1996. Telling Lives in Science: Essays on Scientific Biography. Cambridge: Cambridge University Press.

Singer, Wendy. 2002. "Pure Science: Marie Curie and the American Gift." The Kenyon Review 94112.

Spender, Dale. 1982. Women of Ideas and What Men Have Done to Them. Harper Collins.

Trotereau, J. 2011. Marie Curie. Paris: Gallimard.

Tuchman, Gaye. 1980. “Discriminating Science." Social Policy 11 (May-June): 60-64.

Tuchman, Gaye and Fortin, Nina. 1984. "Fame and Misfortune: Edging Women Out of the Great Literary Tradition." American Journal of Sociology 90 (1): 72-96.

Turnbull, B. 2007. "Female Science Students Get a Boost from Marie Curie; Association Honors Framed Scientist's Polish Roots with Scholarships for Physics and Chemistry Study," Toronto Star, March 8.

Unknown. 2006. “Who Has Won the Most Nobel Prizes? The Ottawa Citizen. December 10, A2.

Venezia, Mike. 2009. Marie Curie: Scientist Who Made Glowing Discoveries. New York: Children's Press.

Waltar, Alan. 2004. Radiation and Modern Life: Fulfilling Marie Curie's Dream. New York: Prometheus Books.

Wishinsky, Frieda. 2003. Manya's Dream: A Story of Marie Curie. Toronto: Maple Tree Press. 